\title{
Hubungan Pengetahuan Ibu tentang Buku KIA dengan Kunjungan K4
}

\section{The Relationship of Mother's Knowledge about MCH Handbook with K4 Visit}

\author{
Apriyanti Sihole \\ Program Studi Ilmu Kesehatan Masyarakat, Universitas Sumatera Utara, Indonesia
}

\section{ARTICLE INFO}

\section{Article history}

Received date

25 Aug 2020

Revised date

10 Sept 2020

12 Oct 2020

Accepted date

14 Oct 2020

\section{Keywords:}

MCH Handbook;

Public health center;

Visit.

\section{Kata kunci:}

Buku KIA;

Puskesmas;

Kunjungan.

\author{
ABSTRACT/ ABSTRAK
}

The MCH Handbook (Maternal and Child Health) can be used as a basic tool to maximize the quality of life for mothers, children, and families around the world. This book is used as a basic record for mothers and children in more than 30 countries in the world. The $\mathrm{MCH}$ book contains records of maternal health from pregnancy to child care up to 6 years of age. The coverage of KIA book ownership at the Teluk Belengkong Health Center was $27 \%$ below the district level, namely $59,4 \%$, while the coverage of KI visits was $27 \%$ and K4 was $23,03 \%$. This study aims to determine the relationship between a mother's knowledge of the KIA book and K4 visits at the Teluk Belengkong Health Center. This research is quantitative research with a survey method. The number of respondents was 35 people. Knowledge data and the 4th visit were obtained through a checklist sheet and a list of visits to the Puskesmas. The results showed that $65,7 \%$ of respondents had good knowledge, while $34,3 \%$ of respondents had less knowledge. $40 \%$ of respondents had K4 visits and $60 \%$ of respondents did not make K4 visits. Statistical test using chi-square with the results of the $t$ value of 19,22 is greater than $t$ table 3,841 at the $95 \%$ confidence level. So it can be concluded that there is a relationship between a mother's knowledge of the KIA book and K4 visits at the Teluk Belengkong Community Health Center.

\begin{abstract}
Buku KIA (Kesehatan Ibu dan Anak) dapat digunakan sebagai alat dasar untuk memaksimalkan kualitas hidup ibu, anak dan keluarga di seluruh dunia. Buku ini digunakan sebagai basic record ibu dan anak di lebih dari 30 negara di dunia. Di dalam buku KIA berisi catatan kesehatan ibu semenjak hamil hingga perawatan anak hingga berusia 6 tahun. Cakupan kepemilikan buku KIA di Puskesmas Teluk Belengkong sebesar $27 \%$ berada di bawah capaian Kabupaten yaitu 59,4\%, sedangkan cakupan kunjungan K1 sebesar 27\% dan K4 sebesar 23,03\%. Penelitian ini bertujuan untuk mengetahui hubungan pengetahuan ibu tentang buku KIA dengan kunjungan K4 di Puskesmas Teluk Belengkong. Penelitian merupakan penelitian kuantitatif dengan metode survey. Jumlah responden sebesar 35 orang. Data pengetahuan dan kunjungan ke-4 diperoleh melalui lembar checlist dan daftar kunjungan di Puskesmas. Hasil penelitian menunjukkan sebanyak $65,7 \%$ responden mempunyai pengetahuan yang baik, sedangkan 34,3\% responden mempunyai pengetahuan kurang. Sebanyak $40 \%$ responden melakukan kunjungan $\mathrm{K} 4$ dan 60\% responden tidak melakukan kunjungan K4. Uji statistik menggunakan chi square dengan hasil nilai t hitung 19,22 lebih besar dari t tabel 3,841 pada taraf kepercayaan 95\%. Sehingga dapat disimpulkan bahwa ada hubungan pengetahuan ibu tentang buku KIA dengan kunjungan K4 di puskesmas Teluk Belengkong.
\end{abstract}

Corresponding Author:

Apriyanti Sihole

Program Studi Ilmu Kesehatan Masyarakat, Universitas Sumatera Utara, Indonesia

Email: apriyantisihole@gmail.com

\section{PENDAHULUAN}

Buku Kesehatan Ibu dan Anak (KIA) merupakan alat yang digunakan untuk memantau perkembangan ibu dan anak sampai usia 6 tahun. Masyarakat awam lebih mengenal buku ini dengan sebutan buku pink dikarenakan warna dominan adalah warna pink. Buku ini pertama kali digunakan di negara Jepang yang dikenal dengan sebutan Boshi techo (buku ibu). Pada Tahun 1980 pemerintah Indonesia bekerjasama dengan JICA (Japan International Coorporation 
Agency) dalam satu program internship untuk melakukan uji coba penggunaan buku KIA di Salatiga. Pada Tahun 2006 penggunaan buku KIA menjadi program nasional dalam upaya pemerintah untuk menekan angka kematian ibu dan anak yang masih tinggi di Indonesia.

Buku KIA merupakan sarana awal yang dimanfaatkan untuk mengetahui adanya gangguan atau masalah kesehatan ibu dan anak, sebagai media komunikasi dan edukasi yang memberikan informasi yang penting bagi ibu dan keluarga dan masyarakat mengenai pelayanan kesehatan ibu dan anak termasuk berkaitan dengan rujukannya. Tujuan penggunaan buku ini adalah meningkatkan kemandirian keluarga dalam memelihara kesehatan ibu dan anak. Pemerintah berharap dengan penggunaan buku KIA secara efektif dapat menekan angka kematian ibu dan anak.

Sebagai buku yang telah digunakan di 30 negara di dunia, WHO (World Health Organization) dalam konferensi Maternal and Child Handbook yang diadakan di Bangkok Tahun 2018 memberikan rekomendasi penggunaan buku KIA sebagai alat dasar rekam medis keluarga di seluruh dunia. Hal yang sama juga di nyatakan oleh World Medical Assosiation mendukung pengembangan dan meningkatkan promosi penggunaan buku KIA di seluruh dunia (Nakamura, 2019).

Indonesia sendiri berada di urutan ke 2 di negara-negara ASEAN dengan angka kematian ibu yang masih tinggi yaitu 305 ibu per 100.000 kelahiran hidup. Berada di bawah nilai kematian ibu rata-rata negara ASEAN yakni 197 ibu per 100.000 kelahiran hidup. Angka ini dapat menggambarkan kurangnya pemantauan kesehatan ibu hamil dan perkembangan anak baik oleh tenaga kesehatan terutama oleh keluarga terdekat (Badan Penelitian dan Pengembangan Kesehatan, 2016).

Sebagian penyebab kematian ibu secara langsung adalah komplikasi yang terjadi pada saat persalinan dan segera setelah bersalin. penyebab tersebut dikenal dengan trias klasik yaitu pendarahan, eklampsia dan infeksi. Berdasarkan laporan dari Dinas Kesehatan Kabupaten Indragiri Hilir (2019) bahwa penyebab kematian diantaranya "4 terlalu" dan "3 terlambat". Empat terlalu antara lain terlalu muda (usia kurang dari 20 tahun), terlalu tua (usia lebih dari 35 tahun), terlalu sering (jarak antara kelahiran kurang dari 2 tahun), atau terlalu banyak (jumlah anak kurang dari 3 tahun lebih dari 2). sedangkan 3 terlambat anatara lain terlambat mengenali tanda bahaya dalam memutuskan dirujuk ke fasilitas kesehatan, terlambat mencapai fasilitas kesehatan, serta terlambat mendapatkan pelayanan di fasilitas kesehatan. Pemeriksaan ANC yang tidak teratur sejak awal kehamilan menyebabkan terlambatnya deteksi ibu hamil beresiko.

Telah banyak penelitian yang dilakukan baik di dalam nergeri maupun di luar negeri mengenai manfaat penggunaan buku KIA. Penelitian yang dilakukan oleh Osaki, Hattori, Toda, Mulati (2019) di Jawa menyatakan bahwa penggunaan buku KIA meningkatkan perawatan berkelanjutan di rumah mulai dari kehamilan sampai pada perawatan bayi baru lahir. Pernyataan ini sama dengan hasil penelitian yang dilakukan oleh Magwood, et al, (2019) secara sistematik review dan meta analisis. Banyak faktor yang memperngaruhi penggunaan buku KIA, seperti hasil penelitian dari Hikita, et al, (2018) di Mongolia bahwa tingkat kecerdasan, pendidikan, ekonomi dan edukasi berpengaruh pada efektivitas penggunaan buku KIA.

Penelitian yang dilakukan Iryani (2020) di Puskesmas Pasir Putih Manokwari menyatakan bahwa faktor pengetahuan, sikap, umur dan pekerjaan mempengaruhi keteraturan kunjungan K1 dan K4. Faktor yang lebih banyak diungkapkan melalui penelitian yang dilakukan oleh Nurmawati (2018) di Puskesmas Klambu bahwa selain pengetahuan, sikap, umur dan pekerjaan, faktor lain yang berhubungan dengan cakupan kunjungan ANC adalah jarak kehamilan, media informasi, dukungan suami dan dukungan petugas kesehatan.

Data Dinas Kesehatan Kabupaten Indragiri Hilir Tahun 2019 menunjukkan bahwa kepemilikan buku KIA mencapai 53,59\%. Capaian ini masih jauh dibawah capaian nasional berdasarkan data hasil Riskesdas Tahun 2018 sebesar 70\%. Puskesmas Di Kabupaten Indragiri Hilir yang capaian kepemilikan paling rendah berada di Puskesmas Teluk Belengkong dengan capaian 27\%. Data kunjungan K1 pada Puskesmas Teluk Belengkong Tahun 2019 sebesar 27\% dan kunjungan K4 sebesar 23,03\%.

Penelitian yang dilakukan oleh Kaneko, et al, di Burundi (2017) menyatakan bahwa kepemilikan buku KIA secara signifikan meningkatkan jumlah ibu hamil yang melakukan pemeriksaan kesehatan di fasilitas kesehatan. Penelitian lain yang dilakukan oleh Rejeki, dkk di Slawi (2019) menyatakan hasil yang berbeda bahwa tidak ada hubungan antara pemanfaatan buku KIA dengan kepatuhan antenatal care. Hasil yang sama dinyatakan oleh Oktarina (2013) yang melakukan penelitian di Jawa Timur.

Dari data tersebut maka perlu dilakukan penelitian dengan tujuan untuk mengetahui 
hubungan pengetahuan ibu tentang buku KIA dengan kunjungan K4 di Puskesmas Teluk Belengkong.

\section{METODE}

Metode yang digunakan dalam penelitian ini adalah penelitian deskriptif dengan dengan metode survei. Lokasi penelItian adalah Puskesmas Teluk Belengkong yang mempunyai capaian K1 dan K4 terendah di wilayah Kabupaten Indragiri Hilir. Sampel dalam penelitian ini berjumlah 35 orang ditentukan dengan teknik simple random sampling dengan sistem cabut undian. Nomor urut setiap populasi di buat di dalam kertas kecil kemudian kertas digulung dan dimasukkan ke dalam wadah berupa botol. Botol dikocok dan dikeluarkan kertas satu persatu sampai mencapai jumlah sampel yang diinginkan.

Metode pengumpulan data dilakukan dengan kuesioner yang telah mendapat persetujuan Komisi Etik Penelitian Kesehatan Fakultas Keperawatan Universitas Sumatera Utara dengan nomor 2197/VII/SP/2020. Kuesioner berisi pertanyaan terbuka kepada ibu hamil yang menjadi sampel, pengecekan lembar cheklist di buku KIA, dan data pencatatan kunjungan ibu hamil di Puskemas Teluk
Belengkong. Penelitian dilakukan dari 8-22 Juni 2020.

\section{HASIL}

Tabel 1. Distribusi Pengetahuan Ibu Hamil tentang Buku KIA

\begin{tabular}{lcc}
\hline \multicolumn{1}{c}{$\begin{array}{c}\text { Pengetahuan ibu hamil } \\
\text { tentang buku KIA }\end{array}$} & $\mathbf{n}$ & $\boldsymbol{\%}$ \\
\hline Pengetahuan baik & 23 & 65,7 \\
Pengetahuan kurang & 12 & 34,3 \\
\hline
\end{tabular}

Hasil penelitian menunjukkan bahwa sebanyak 23 orang $(65,7 \%)$ responden memiliki pengetahuan yang baik dan 12 orang $(34,3 \%)$ responden memiliki pengetahuan yang kurang baik tentang buku KIA.

\section{Tabel 2. Distribusi Kunjungan K4 Ibu Hamil}

\begin{tabular}{lll}
\hline \multicolumn{1}{c}{ Kunjungan K4 } & n & \% \\
\hline Melakukan kunjungan & 14 & 40 \\
Tidak melakukan kunjungan & 21 & 60 \\
\hline
\end{tabular}

Sedangkan tabel 2 menunjukkan data kunjungan K4 di Puskesmas Teluk Belengkong yaitu sebanyak 14 orang (40\%) responden melakukan kunjungan K4 dan selebihnya 21 orang $(60 \%)$ responden tidak melakukan kunjungan $\mathrm{K} 4$.

Tabel 3. Hubungan Pengetahuan Ibu Tentang Buku KIA dengan Kunjungan K4

\begin{tabular}{|c|c|c|c|c|c|c|c|}
\hline \multirow{3}{*}{$\begin{array}{l}\text { Pengetahuan ibu hamil } \\
\text { tentang buku KIA }\end{array}$} & \multicolumn{4}{|c|}{ Kunjungan k4 } & \multicolumn{2}{|c|}{ TOTAL } & \multirow{3}{*}{ p-value } \\
\hline & \multicolumn{2}{|c|}{$\begin{array}{l}\text { Melakukan } \\
\text { kunjungan }\end{array}$} & \multicolumn{2}{|c|}{$\begin{array}{c}\text { Tidak melakukan } \\
\text { kunjungan }\end{array}$} & \multirow[t]{2}{*}{ n } & \multirow[t]{2}{*}{$\%$} & \\
\hline & $\mathbf{n}$ & $\%$ & $\mathrm{n}$ & $\%$ & & & \\
\hline Pengetahuan baik & 8 & 22,9 & 15 & 42,9 & 23 & 65,7 & 2 \\
\hline Pengetahuan kurang & 6 & 17,1 & 6 & 17,1 & 12 & 34,3 & 19,22 \\
\hline
\end{tabular}

Untuk melihat hubungan antara pengetahuan dan kunjungan K4 ibu hamil dilakukan uji Chi square. Dari tabel 3 diketahui bahwa ibu yang mempunyai pengetahuan baik dan melakukan kunjungan $\mathrm{K} 4$ sebanyak 8 orang $(22,9 \%)$, sedangkan yang tidak melakukan kunjungan K4 sebanyak 15 orang $(42,9 \%)$. Sementara itu jumlah ibu yang mempunyai pengathuan kurang dan melakukan kunjungan K4 sebanyak 6 orang $(17,1 \%)$ sedangkan yang tidak melakukan kunjungan sebanyak 6 orang $(17,1 \%)$. Hasil uji statistik menggunakan chi square di peroleh hasil nilai t hitung sebesar 19,22 lebih besar dari nilai t tabel untuk derajat kepercayaan $95 \%$ yaitu 3,841. Maka dapat disimpulkan bahwa ada hubungan antara pengetahuan ibu tentang buku KIA dengan kunjungan K4 di Puskesmas Teluk Belengkong.

\section{PEMBAHASAN}

Buku KIA merupakan alat untuk mendeteksi secara dini adanya gangguan atau masalah kesehatan ibu dan anak, alat komunikasi dan penyuluhan dengan informasi yang penting bagi ibu, keluarga dan masyarakat mengenai pelayanan, kesehatan ibu dan anak termasuk rujukannya dan paket (standar) pelayanan KIA, gizi, imunisasi dan tumbuh kembang balita (Kementerian Kesehatan RI, 2014).

Salah satu tujuan penggunaan buku Kesehatan Ibu dan Anak (KIA) adalah meningkatkan kemandirian keluarga dalam memelihara kesehatan ibu dan anak. Dalam keluarga, ibu dan anak merupakan kelompok yang paling rentan terhadap berbagai masalah kesehatan seperti kesakitan dan gangguan gizi 
yang sering kali berakhir dengan kecacatan atau kematian. Untuk mewujudkan kemandirian keluarga dalam memelihara kesehatan ibu dan anak maka salah satu upaya program adalah meningkatkan pengetahuan dan keterampilan keluarga melalui penggunaan Buku Kesehatan Ibu dan Anak (Kementerian Kesehatan RI, 2015).

Hasil penelitian mengenai pengetahuan ibu tentang buku KIA di Puskesmas Teluk Belengkong sebanyak 23 orang $(65,7 \%)$ memiliki pengetahuan yang baik dan 12 orang $(34,3 \%)$ memiliki pengetahuan kurang. Dari data ini dapat di simpulkan bahwa lebih dari 50\% ibu hamil yang memiliki buku KIA sudah memiliki pengetahuan yang baik. Artinya informasi yang terdapat di dalam buku KIA dapat dimengerti oleh ibu dan keluarga.

Meskipun capaian kepemilikian buku KIA saat ini di Puskesmas Teluk Belengkong sebesar $27 \%$ merupakan capaian paling rendah di Kabupaten Indragiri Hilir, tetapi cakupan pengetahuan ibu yang tinggi membuktikan bahwa buku KIA sudah maksimal digunakan. Adanya dukungan dari tenaga kesehatan dan kesadaran dari ibu dan keluarga menjadikan buku KIA sebagai sumber informasi kesehatan ibu hamil dan perawatan anak sampai usia 6 tahun.

Kesadaran dapat muncul dari kebutuhan yang dirasakan, dalam hal ini adanya kebutuhan ibu hamil untuk menjaga kesehatannya agar tetap baik menjelang waktu melahirkan. Kemudian ibu akan mulai mencari sumber informasi yang dapat digunakan sebagai referensi salah satunya adalah buku KIA yang sudah diperoleh dari layanan kesehatan. Tidak semua informasi yang diperoleh dapat langsung dimengerti oleh ibu dan keluarga, sehingga tenaga kesehatan berperan sebagai komunikator yang bertanggungjawab menjelaskan informasi buku KIA secara rinci kepada ibu dan keluarga.

Buku KIA selain sebagai media komunikasi dan edukasi bagi ibu dan keluarga juga digunakan sebagai catatan pelayanan kesehatan ibu hamil yang di kenal dengan antenatal care (ANC). Antenatal care merupakan perawatan yang diberikan pada ibu selama masa kehamilan, dimulai dari awal kehamilan sampai proses melahirkan selama 40 minggu lamanya. Pelayanan ini bertujuan untuk mendeteksi secara dini adanya gangguan pada ibu selama proses kehamilan sampai melahirkan.

ANC terpadu merupakan salah satu program yang disusun oleh Kementerian Kesehatan RI untuk dapat mendeteksi dini masalah/ gangguan pada ibu hamil. Diharapkan dengan pelaksanaan ANC di puskesmas maka status kesehatan ibu hamil akan meningkat dan menurunkan angka kematian ibu. Standar pelaksanaan ANC yang berkualitas yaitu memberikan pelayanan kepada ibu hamil minimal 4 kali, yaitu 1 kali pada trimester I, 1 kali pada trimester II, dan 2 kali pada trimester III untuk memantau keadaan ibu dan janin dengan seksama, sehingga dapat mendekti secara dini dan dapat memberikan intervensi secara tepat (Kementerian Kesehatan RI, 2010).

Untuk menilai pencapaian kunjungan ANC dilihat dari pencapaian K1 dan K4. K1 merupakan kontak awal ibu hamil dengan tenaga kesehatan dengan tujuan mendapatkan pemeriksaan kesehatan awal dan buku KIA. Kunjungan ulang (K4) bertujuan untuk mendeteksi kehamilan beresiko. Semakin baik cakupan K4 akan semakin cepat mendeteksi gangguan kehamilan dan mencegah kematian akibat kehamilan.

Tujuan pemeriksaan K1 dan K4 adalah untuk menajga agar ibu sehat selama amsa kehamilan, persalinan dan nifas serta mengusahakan bayi yang dilahirkan sehat. Memantau kemungkinan adanya resiko kehamilan dan merencanakan penatalaksanaan yang optimal terhadap kehamilan beresiko tinggi. Serta menurukan morbiditas dan mortalitas ibu dan perinatal.

Selama melakukan kunjungan untuk asuhan antenatal, para ibu hamil akan mendapatkan serangkaian pelayanan yang terkait dengan upaya memastikan ada tidaknya kehamilan dan penelusuran berbagai kemungkinan adanya penyulit atau gangguan kesehatan selama kehamilan yang mungkin dapat mengganggu kualitas kehamilan. Identifikasi kehamilan diperoleh melalui seperti perubahan anatomi dan fisiologi kehamilan seperti yang telah diuraikan sebelumnya.

Capaian kunjungan K1 Puskesmas Teluk Belengkong sebesar 27\% dengan capaian K4 yang lebih kecil sebesar 23,03\%. Hasil penelitian lebih rinci menunjukkan bahwa responden yang melakukan kunjungan K4 sebanyak 14 orang (40\%) lebih sedikit dari responden yang tidak melakukan kunjungan K4 yaitu 21 orang $(60 \%)$. Dari data ini diperoleh informasi bahwa tidak semua ibu hamil melakukan pemeriksaan kesehatan sesuai yang telah di standartkan sebanyak minimal 4 kali.

Cakupan K1 dibawah 70\% menunujukkan keterjangkauan pelayanan antenatal yang rendah, yang mungkin disebabkan oleh pola pelayanan yang belum cukup aktif. Rendahnya K1 menunjukkan bahwa akses petugas kepada ibu masih perlu ditingkatkan. Tujuan K1 adalah untuk mendeteksi adanya gangguan kehamilan 
yang dapat mengancam kesehatan ibu dan anak. Agar tujuan tersebut tercapai pemeriksaan kehamilan harus segera dilaksanakan begitu terjadi kehamilan yaitu ketika haidnya terlambat sekurang-kurangnya 1 bulan.

Cakupan K4 dibawah $60 \%$ menunjukkan kualitas pelayanan antenatal care yang belum memadai. Rendahnya K4 menunjukkan rendahnya kesempatan untuk menajring dan menangani kehamilan beresiko. Dengan pelayanan yang baik, dapat diidentifikasi kehamilan beresiko tinggi dan dilanjutkan dengan perawatan khusus sehingga dapat menekan angka kematian ibu.

Banyak faktor yang mempengaruhi tidak terlaksananya pelayanan antenatal care selama kehamilan terakhir, baik dari fasilitas pelayanan kesehatan maupun ibu yang tidak ingin melakukan kunjungan. Fasilitas kesehatan berkaitan dengan tenaga kesehatan, kualitas pelayanan dan akses terhadap pelayanan kesehatan. Sedangkan ibu yang tidak ingin melakukan kunjungan berkaitan dengan demografi, tingkat pengetahuan ibu, sikap, dan dukungan orang terdekat.

Penelitian yang dilakukan Iryani (2020) di Puskesmas Pasir Putih Manokwari menyatakan bahwa faktor pengetahuan, sikap, umur dan pekerjaan mempengaruhi keteraturan kunjungan K1 dan K4. Peneltian lain yang dilakukan oleh Salamah (2019) di Puskesmas Teupin Raya menunjukkan hasil bahwa ada hubungan umur, pengetahuan, jarak dan kualitas pelayanan serta dukungan suami terhadap kunjungan kehamilan K4.

Wilayah kerja Puskesmas Teluk Belengkong yang secara geografis terdiri dari tanah gambut dan dipisahkan oleh kanal-kanal kecil membuat ibu hamil yang tinggal jauh dari puskesmas maupun puskesmas pembantu enggan untuk melakukan pemeriksaan kehamilan. Selain jarak yang jauh, sarana transportasi yang tersedia berupa boat dengan biaya yang cukup tinggi. Jika ingin menghemat biaya tansportasi perjalanan di tempuh dengan menggunakan kendaraan roda dua melalui jalan gambut yang jika hujan akan sulit dilewati.

Selain kondisi geografis yang sulit, rendahnya kunjungan K4 di Puskesmas Teluk Belengkong dikarenakan adanya ibu yang melakukan perjalanan keluar daerah atau ke kabupaten dengan alasan ingin mendapatkan fasilitas yang lebih baik sampai keinginan untuk melahirkan di rumah orang tua. Lokasi Kecamatan Teluk Belengkong yang jauh dari pusat kabupaten yang harus ditempuh dengan menggunakan sarana transportasi air berupa bot selama kurang lebih 5 jam dan keterbatasan alat medis yang tersedia di puskesmas menjadi pertimbangan bagi ibu untuk melakukan persalinan di puskesmas. Ibu hamil yang memiliki kekhawatiran untuk melahirkan di puskesmas lebih memilih untuk melahirkan di rumah sakit yang terdapat di Kabupaten, sehingga semakin sedikit ibu hamil yang melakukan kunjungan K4 di puskesmas. Keinginan untuk melahirkan di rumah orang tua yang terdapat di luar kecamatan juga mempengaruhi jumlah kunjungan K4. Bagi ibu hamil yang tidak bekerja sementara suami adalah seorang pekerja, akan memilih untuk melahirkan di rumah orang tua karena ada yang membantu dalam proses pemulihan selepas melahirkan nantinya.

Keterbatasan dan ketidakhadiran tenaga kesehatan di tempat tugas juga dapat menurunkan capaian kunjungan K4. Ibu hamil beresiko yang terdeteksi saat melakukan pemeriksaan ANC juga disarankan untuk melahirkan di rumah sakit sehingga capaian kunjungan K4 akan semakin berkurang.

Ditambah dengan kondisi pandemi covid 19 saat ini, semakin sedikit ibu hamil yang melakukan kunjungan ANC. Ibu hamil lebih beresiko terinfeksi virus corona karena daya tahan tubuhnya yang cenderung lebih lemah. Hal ini menimbulkan rasa takut yang dirasakan oleh ibu dan keluarga sehingga enggan untuk berkunjung kelayanan kesehatan kecuali jika dalam kondisi darurat. Beberapa hal telah dilakukan untuk mengatasi permasalahan ini, dimana Puskesmas di wilayah kerja Kabupaten Indragiri Hilir melakukan kunjungan rumah dalam rangka pemeriksaan ANC. Tetapi kunjungan rumah dilakukan hanya pada ibu hamil beresiko, sehingga belum dapat menjangkau semua ibu hamil

Hasil analisa statistik dalam penelitian ini menunjukkan angka t hitung yang lebih besar dari t tabel yaitu 19,22>8,314, sehingga $\mathrm{H}_{0}$ di tolak. Bahwasanya pengetahuan ibu tentang buku KIA berhubungan dengan kunjungan $\mathrm{K} 4 \mathrm{di}$ Puskesmas Teluk Belengkong. Hasil ini sesuai dengan hasil penelitian yang dilakukan oleh Kaneko, et al di Burundi (2017) menyatakan bahwa kepemilikan buku KIA secara signifikan meningkatkan jumlah ibu hamil yang melakukan pemeriksaan kesehatan di fasilitas kesehatan.

Berbeda dengan hasil penelitian yang dilakukan oleh Rejeki, dkk (2019) menyatakan hasil yang berbeda bahwa tidak ada hubungan antara pemanfaatan buku KIA dengan kepatuhan antenatal care. Hasil yang sama dinyatakan oleh 
Oktarina (2013) yang melakukan penelitian di Jawa Timur.

Kunjungan K4 dapat digolongkan sebagai suatu tindakan karena merupakan suatu perbuatan, aksi atau perilaku yang dilakukan manusia sepanjang hidupnya untuk tujuan tertentu. Ibu hamil melakukan kunjungan K4 dengan tujuan memantau kesehatan kehamilan untuk meminimalisir resiko saat melahirkan. Pengetahuan akan kunjungan K4 dapat diperoleh ibu melalui berbagai cara baik melalui media informasi (cetak atau elektronik), tenaga kesehatan maupun orang-orang dilingkungan sekitar. Informasi yang diperoleh akan meningkatkan pengetahaun ibu tentang pentingnya melakukan kunjungan K4.

Domain perilaku menurut Bloom terdiri dari pengetahuan (domain kognitif), sikap (domain afektif) dan tindakan (domain psikomotor). Pengetahuan atau domain kognitif merupakan domain yang sangat penting untuk terbentuknya tindakan seseorang (overt behaviour). Berdasarkan pengalaman ternyata perilaku yang didasari oleh pengetahuan akan lebih langgeng dari pada perilaku yang tidak didasari oleh pengetahuan.

Sikap secara nyata menunjukkan konotasi adanya kesesuaian reaksi terhadap pengetahuan yang diperoleh. Sikap juga merupakan kesiapan atau kesediaan untuk bertindak dan bukan pelaksanaan motif tertentu. Sikap belum merupakan suatu tindakan atau aktivitas akan tetapi merupakan predisposisi tindakan atau

\section{DAFTAR PUSTAKA}

Badan Penelitian dan Pengembangan Kesehatan. (2016). 7 Rekomendasi Terkait Angka Kematian Ibu di Indonesia. Jakarta.

http://www.litbang.kemkes.go.id/7rekomendasi-terkait-angka-kematian-ibuindonesia/

Kementerian Kesehatan RI. (2015). Juknis Penggunaan Buku KIA. Jakarta: Departemen Kesehatan dan JICA (Japan International Cooperation Agency).

Dinas Kesehatan Kabupaten Indragiri Hilir. (2019). Profil Dinas Kesehatan Kabupaten Indragiri Hiir Tahun 2018. Indragiri Hilir.

Hikita, N., Haruna, M., Matsuzaki, M., Shiraishi, M., Takehara, K., Dagvadorj, A., ... \& Mori, R. (2018). Utilisation of maternal and child health handbook in Mongolia: A perilaku. Sikap itu masih merupakan reaksi tertutup, bukan merupakan reaksi terbuka atau tingkah laku yang terbuka. Lebih dapat dijelaskan lagi bahwa sikap merupakan reaksi terhadap objek di lingkungan tertentu sebagai suatu penghayatan terhadap objek.

Tindakan (domain psikomotor) merupakan suatu perbuatan nyata yang dapat diamati atau dilihat. Suatu sikap belum otomatis terwujud dalam bentuk tindakan (overt behavior). Untuk terwujudnya sikap menjadi suatu perbuatan nyata diperlukan faktor pendukung atau suatu kondisi yang memungkinkan, antara lain adalah fasilitas.

Sikap ibu yang sudah positif terhadap kunjungan $\mathrm{K} 4$ harus mendapat konfirmasi dari suaminya, dan ada fasilitas imunisasi yang mudah dicapai, agar ibu tersebut melakukan kunjungan K4. Disamping faktor fasilitas juga diperlukan faktor dukungan (support) dari pihak lain, misalnya suami, orang tua atau mertua sangat penting untuk mendukung tindakan ibu melakukan kunjungan $\mathrm{k} 4$.

\section{SIMPULAN}

Terdapat hubungan antara pengetahuan ibu hamil tentang buku KIA dengan kunjungan K4. Semakin baik pengetahuan ibu hamil tentang buku KIA maka akan semakin besar kemungkinan ibu untuk melakukan kunjungan K4 di Puskesmas. cross-sectional study. Health Education Journal, 77(4), 458-469. https://doi.org/10.1177/0017896917753649

Iryani, D., Kebidanan, D., Kesehatan, P., \& Sorong, K. (2020). Faktor Yang Mempengaruhi Cakupan Pemeriksaan K1 Dan. Nursing Arts, XIV(01), 42-52.

Kaneko, K., Niyokun, J., Juma, N., Mbonabuca, T., Osaki, K. \& Aoyama, A. (2017). Effectiveness of The Maternal and Child handbook in Burundi for increasing notification of birth at health facilities and postnatal care uptake. Jurnal Global Helath Action. 10:1, 1297604, doi: 10.1081/166497/2017.1297604.

Kementerian Kesehatan RI. (2010). Pedoman Pelayanan ANC Terpadu. Jakarta: Ditjen Bina Kesehatan Masyarakat Kemenkes RI. 
Kementerian Kesehatan RI. (2014). Keputusan Menteri Kesehatan Republik Indonesia Nomor 284 Tahun 2004 Tentang Buku Kesehatan Ibu dan Anak. Jakarta.

Magwood, O., Kpadé, V., Thavorn, K., Oliver, S., Mayhew, A. D., \& Pottie, K. (2019). Effectiveness of home-based records on maternal, newborn and child health outcomes: A systematic review and metaanalysis. PloS one, 14(1), e0209278. https://doi.org/10.1371/journal.pone.0209278

Nakamura, Y. (2019). The Role of Maternal and Child Health $(\mathrm{MCH})$ Handbook in the era of sustainable development goals (SDG's). J Glob Health Sci, 1,24. doi:10.35500/jghs.2019.1.e24

Nurmawati, N., \& Indrawati, F. (2018). Cakupan Kunjungan Antenatal Care pada Ibu Hamil. HIGEIA (Journal of Public Health Research and Development), 2(1), 113-124. https://journal.unnes.ac.id/sju/index.php/hi geia/article/view/18317

Oktarina, M. (2013). Hubungan Pengetahuan, Sikap, Kepatuhan Ibu Hamil, dan Ibu Bayi dalam Penggunaan Buku KIA di
Puskesmas Geger dan Kedundung Kabupaten Bangkalan. Buletin Penelitian Sistem Kesehatan, 18(2), 141150.

Osaki, K., Hattori, T., Toda, A., Mulati, E., Hermawan, L., Pritasari, K., Bardosono, S., \& Kosen, S. (2019). Maternal and Child Health Handbook use for maternal and child care: a cluster randomized controlled study in rural Java, Indonesia. Journal of public health (Oxford, England), 41(1), 170-182. https://doi.org/10.1093/pubmed/fdx175

Rejeki, T.S., Hadiningsih, T.A. \& Wahyuningsih, R.F. (2019). Pemanfaatan Buku KIA dalam Kunjungan Ibu Hamil Trimester III di Wilayah Kerja Puskesmas Salwi. Jurnal SMART Kebidanan. (1). 25-3-. doi: 10.34310/sjkb.V6i1.236

Salamah, Salamah \& Humaira, Putri \& Riskina, Zulfa. (2019). Faktor-Faktor Yang Berpengaruh Terhadap Kunjungan K4 Di Wilayah Kerja Puskesmas Teupin Raya Kabupaten Pidie Tahun 2017. Journal of Healthcare Technology and Medicine. 5. 373. 10.33143/jhtm.v5i2.486 